BIOMEDICAL AND BIOSOCIAL ANTHROPOLOGY
$\begin{gathered}\text { Official Journal of the International Academy } \\ \text { of Integrative Anthropology } \\ \text { journal homepage: http://bba-journal.com }\end{gathered}$

\title{
Qualitative signs of digital dermatoglyphics as markers of diseases of atopic nature
}

\author{
Cherkasov V. G., Maievskyi O. Ye., ${ }^{1}$ Serheta I. V., ${ }^{2}$ Makarchuk I. M., ${ }^{2}$ Smolko N. M. ${ }^{2}$ \\ Bogomolets National Medical University, Kyiv, Ukraine \\ ${ }^{1}$ Taras Shevchenko National University of Kyiv, Kyiv, Ukraine \\ ${ }^{2}$ National Pirogov Memorial Medical University, Vinnytsya, Ukraine
}

\section{ARTICLE INFO}

Received: 24 December 2018

Accepted: 14 January 2019

UDC: $340.6: 616.516 .5$

\section{CORRESPONDING AUTHOR}

e-mail: maevskyalex8@gmail.com Maievskyi O. Ye.

\begin{abstract}
The lawfulness of the application of the method of dermatoglyphics in the study of atopic diseases is ensured by the polygenic inheritance of signs of dermatoglyphics, on the one hand, and the pathogenetic heterogeneity of these diseases, on the other hand, as well as high informative ability of signs of dermatoglyphics as markers of diseases of hereditary and multifactorial nature. The purpose of the study is to detect differences in qualitative signs of digital dermatoglyphics between patients with atopic dermatitis, allergic rhinitis and bronchial asthma. Primary indicators of digital dermatoglyphics of sick young men and young women of the Podillia region are taken from the data bank of the research center of the National Pirogov Memorial Medical University, Vinnytsya and were used in previous studies when compared with the practically healthy population of this region. Imprints were obtained by the method of "printing ink" by Gladkova T. D. By the method of Cummins H. and Midlo Ch. a dermatological study was performed for 320 young men and young women with allergic rhinitis ( $n=69)$, bronchial asthma $(n=108)$ and atopic dermatitis $(n=143)$. The frequency and location of 8 types of finger patterns were subject to analysis. Statistical processing of the obtained results was carried out in the package "Statistica 6.1" using nonparametric methods. The reliability of the difference in values between independent qualitative values was determined by the formula of Weber $E$. (1961). The specificity of the digital typology of atopic diseases is established, which is based on the differences in the frequency and location of the whorl, central pocket and arches between the young men, except those indicated - a random pattern between young women, patients with atopic dermatitis, bronchial asthma, allergic rhinitis. Additionally, when comparing young men, patients with allergic rhinitis with patients with bronchial asthma and atopic dermatitis - ulnar loop; for bronchial asthma with patients with allergic rhinitis and atopic dermatitis - lateral pocket loop (in young men) and ulnar, lateral pocket and double loops (in young women); when comparing young men, patients with atopic dermatitis with patients with bronchial asthma, and allergic rhinitis - a random pattern. Keywords: types of finger patterns, atopic dermatitis, bronchial asthma, allergic rhinitis.
\end{abstract}

\section{Introduction}

Atopic march is a combination of processes that consists in the predominance of certain manifestations of allergic character in different periods of human development. The classically atopic march begins in childhood in the form of atopic dermatitis, which subsequently changes with allergic rhinitis. At the end of the atopic march there is bronchial asthma [3].

By manifestations of the atopic march are afflicted millions of people around the world and annual increases in incidence of atopic dermatitis and allergic rhinitis and bronchial asthma are recorded [1, 22, 31].

According to Taiwanese scientists, the incidence of atopic dermatitis, allergic rhinitis and bronchial asthma for 8 years (from 2000 to 2007 ) is $6.7 \%, 26.3 \%$ and $11.9 \%$, respectively. Children and adolescents had significantly higher rates of these diseases compared to adults [15]. Korean researchers found that the prevalence of allergic rhinitis was $24.34 \%$ for elementary school students, 
$13.75 \%$ for high school students and $12.17 \%$ for secondary school students [16].

It is noted that individuals of different sex, age and type of body structure are very strikingly affected by these diseases $[6,23,25,26,28,29]$.

Korean scientists surveyed 5202 adult Koreans aged 19 to 40 years. The prevalence of atopic dermatitis tended to be $U$-shaped relative to the body mass index, waist circumference and the percentage of total adipose tissue, especially in women [19].

So, scientists from the USA conducted a study of 8165 people with allergic rhinitis. Multivariate regression was used to assess the relationship between obesity and rhinitis. Excessive weight, obesity or central obesity were not associated with allergic rhinitis in adults. In children, central obesity was associated with a decrease in the chances of allergic rhinitis $(0.35 ; 95 \% \mathrm{Cl}, 0.19-0.64 ; \mathrm{p}<0.01)$. After stratification by gender, this association was similar to that of girls and boys [11].

Indian scientists surveyed 100 patients with allergic rhinitis and asthma and 100 healthy individuals (mean age $30.72 \pm 12.58)$. The odds ratio for patients with allergic rhinitis was $5.05(p<0.05)$. The correlation of allergic rhinitis with the sex was statistically significant $(p<0.05)$. Multiple regression analysis also showed a predisposition for allergic rhinitis with asthma $(p<0.05)[17]$.

In a study that covered 1 million people born in 19521959 , it was found that the relative risk of asthma is associated with an increase in the body mass index of 3 points was ranging from 1.14 (95\% confidence interval 1.10$1.18)$ in smokers to $1.27(1.22-1.32)$ for those who do not smoke [24].

These data are corroborated by many other studies that have also established the link between obesity and the risk of these diseases [4, 14, 18, 30].

A promising area is the study of dermatological markers for allergic rhinitis, bronchial asthma and atopic dermatitis [13]. Dermatoglyphics studies the features of a human skin pattern formed by papillary lines, which in turn form different formations (triadius, loops, arches and whorls patterns). Thus, a unique imprint of a person allows applying this method for the needs of police, in particular, the identification of human [10].

Although dermatoglyphics is a fairly young science - from the moment when Cummins $\mathrm{H}$. and Midlo $\mathrm{Ch}$. presented their main work only about 50 years passed, dermatological features have been already successfully used to predict the development or predisposition to diseases such as diabetes mellitus [21], myocardial infarction [20], etc.

The purpose of the study is to detect differences in qualitative signs of digital dermatoglyphics between patients with atopic rhinitis, bronchial asthma and atopic dermatitis.

\section{Materials and methods}

Primary indices of digital dermatoglyphics of patients with atopic rhinitis, bronchial asthma and atopic dermatitis of young men and young women of the Podillia region are taken from the data bank of the research center of the National Pirogov Memorial Medical University, Vinnytsya and were used in previous studies when compared with practically healthy young men and young women [2, 7, 9].

Selection and examination of patients with atopic dermatitis (AD), bronchial asthma (BA) and allergic rhinitis $(A R)$ were performed in medical institutions of the city of Vinnytsya and the region. The skin allergic tests were performed using a piercing technique using a lancet for a rotary test with injection of mixed allergens produced by the Vinnytsya "Imunolog" Ltd. Clinical and diagnostic criteria for diagnosis of AD were in accordance with generally accepted methods [12]. The verification of the diagnosis of BA was carried out in accordance with the recommendations of the International Expert Group EPR2 , and the AR - according to the recommendations of the ISSA. Dermatoglyphs of 320 adolescents - young men and young women, patients with $A R(n=69$ : young men - 36, young women - 33), BA ( $n=108$ : young men - 63 , young women - 45) and $A D(n=143$ : young men - 64, young women - 79) were studied.

The dermatological study was performed using Cummins $\mathrm{H}$. and Midlo $\mathrm{Ch}$. method [5]. Imprints are obtained by the method of "printing ink" [8]. The frequency and location of 8 types of patterns were subject to analysis.

Statistical processing of the obtained results was carried out in the package "Statistica 6.1" using nonparametric methods. The reliability of the difference in values between independent qualitative values was determined by the Weber E. formula [27].

\section{Results}

The reliable differences or tendencies of qualitative signs of digital dermatoglyphics between patients with allergic rhinitis, bronchial asthma and atopic dermatitis have been established (Table 1-4).

In young men, patients with $A R$ in comparison with patients with $\mathrm{BA}$, on the right hand on the I finger in 7 times more often there observed a whorl, there is no arc, central pocket and lateral pocket loop; on the II finger is extremely rare (difference 8 times) the central pocket; the ulnar loop (more than 1.5 times) predominates on the III finger, and never observed the whorl; on the IV finger, usually, a whorl is recorded (5 times more often) and the central pocket does not appear, most often the whorl (5 times more often) or the ulnar loop (1.3 times more often) are encountered on the $\mathrm{V}$ finger and the central pocket is not found (see Fig. Table 1). Thus, out of 40 analyzed positions of indicators of the right hand, 12 of them obtained reliable differences between patients in the AR and BA.

In young men, patients with $A R$ in comparison with patients with $B A$, on the left hand on the I finger almost 2 times more often observed an ulnar loop and there is no lateral pocket loop; on the II finger the arc dominates (2.5 times) and the central pocket is not found; on the III finger 
Cherkasov V. G., Maievskyi O. Ye., Serheta I. V., Makarchuk I. M., Smolko N. M.

Table 1. Distribution of type of finger patterns on the right hand in young men with allergic rhinitis, bronchial asthma and atopic dermatitis (\%)

\begin{tabular}{|c|c|c|c|c|c|c|c|}
\hline Finger & $\begin{array}{c}\text { Type } \\
\text { of } \\
\text { pattern }\end{array}$ & $\begin{array}{c}\text { Patients } \\
\text { with } A R \\
(\mathrm{n}=36) \\
(1)\end{array}$ & $\begin{array}{c}\text { Patients } \\
\text { with BA } \\
(\mathrm{n}=63) \\
(2)\end{array}$ & $\begin{array}{c}\text { Patients } \\
\text { with } A D \\
(\mathrm{n}=64) \\
(3)\end{array}$ & $p_{1-2}$ & $p_{1-3}$ & $p_{2-3}$ \\
\hline \multirow{8}{*}{ R-I } & A & 0 & 17.46 & 4.69 & $<0.01$ & $>0.05$ & $<0.05$ \\
\hline & $L^{U}$ & 51.52 & 39.68 & 35.94 & $>0.05$ & $>0.05$ & $>0.05$ \\
\hline & $L^{R}$ & 0 & 0 & 0 & $>0.05$ & $>0.05$ & $>0.05$ \\
\hline & W & 24.24 & 3.17 & 12.50 & $<0.01$ & $>0.05$ & $=0.053$ \\
\hline & $\mathrm{CP}$ & 0 & 19.05 & 21.88 & $<0.01$ & $<0.01$ & $>0.05$ \\
\hline & LP & 0 & 12.70 & 0 & $<0.05$ & $>0.05$ & $<0.01$ \\
\hline & $\mathrm{DL}$ & 18.18 & 7.94 & 21.88 & $>0.05$ & $>0.05$ & $<0.05$ \\
\hline & $\mathrm{RP}$ & 0 & 0 & 3.12 & $>0.05$ & $>0.05$ & $>0.05$ \\
\hline \multirow{8}{*}{ R-II } & A & 30.30 & 20.63 & 25.00 & $>0.05$ & $>0.05$ & $>0.05$ \\
\hline & $L^{u}$ & 18.18 & 23.81 & 25.00 & $>0.05$ & $>0.05$ & $>0.05$ \\
\hline & $\mathrm{L}^{\mathrm{R}}$ & 15.15 & 12.73 & 9.37 & $>0.05$ & $>0.05$ & $>0.05$ \\
\hline & W & 27.27 & 20.63 & 9.37 & $>0.05$ & $<0.05$ & $=0.078$ \\
\hline & $\mathrm{CP}$ & 3.03 & 26.98 & 10.94 & $<0.01$ & $>0.05$ & $<0.05$ \\
\hline & LP & 0 & 3.17 & 0 & $>0.05$ & $>0.05$ & $>0.05$ \\
\hline & $\mathrm{DL}$ & 6.06 & 1.59 & 9.37 & $>0.05$ & $>0.05$ & $=0.057$ \\
\hline & $\mathrm{RP}$ & 0 & 3.17 & 10.94 & $>0.05$ & $<0.05$ & $=0.090$ \\
\hline \multirow{8}{*}{ R-III } & A & 6.06 & 9.52 & 25.00 & $>0.05$ & $<0.05$ & $<0.05$ \\
\hline & $L^{u}$ & 69.70 & 42.86 & 54.69 & $<0.05$ & $>0.05$ & $>0.05$ \\
\hline & $\mathrm{L}^{\mathrm{R}}$ & 0 & 0 & 1.56 & $>0.05$ & $>0.05$ & $>0.05$ \\
\hline & W & 18.18 & 17.46 & 7.81 & $>0.05$ & $>0.05$ & $>0.05$ \\
\hline & $\mathrm{CP}$ & 0 & 15.87 & 6.25 & $<0.05$ & $>0.05$ & $=0.086$ \\
\hline & LP & 0 & 6.35 & 0 & $>0.05$ & $>0.05$ & $>0.05$ \\
\hline & $\mathrm{DL}$ & 3.03 & 0 & 3.12 & $>0.05$ & $>0.05$ & $>0.05$ \\
\hline & $\mathrm{RP}$ & 3.03 & 7.94 & 1.56 & $>0.05$ & $>0.05$ & $=0.093$ \\
\hline \multirow{8}{*}{ R-IV } & A & 6.06 & 14.29 & 6.25 & $>0.05$ & $>0.05$ & $>0.05$ \\
\hline & $L^{u}$ & 39.39 & 44.44 & 35.94 & $>0.05$ & $>0.05$ & $>0.05$ \\
\hline & $\mathrm{L}^{\mathrm{R}}$ & 0 & 0 & 0 & $>0.05$ & $>0.05$ & $>0.05$ \\
\hline & W & 51.52 & 3.17 & 14.06 & $<0.001$ & $<0.001$ & $<0.05$ \\
\hline & $\mathrm{CP}$ & 0 & 31.75 & 26.56 & $<0.001$ & $<0.001$ & $>0.05$ \\
\hline & LP & 0 & 0 & 1.56 & $>0.05$ & $>0.05$ & $>0.05$ \\
\hline & $\mathrm{DL}$ & 3.03 & 3.17 & 3.12 & $>0.05$ & $>0.05$ & $>0.05$ \\
\hline & $\mathrm{RP}$ & 0 & 3.17 & 12.50 & $>0.05$ & $<0.05$ & $=0.053$ \\
\hline \multirow{8}{*}{ R-V } & A & 3.03 & 3.17 & 10.94 & $>0.05$ & $>0.05$ & $=0.090$ \\
\hline & $L^{u}$ & 78.79 & 58.73 & 62.50 & $<0.05$ & $=0.096$ & $>0.05$ \\
\hline & $\mathrm{L}^{\mathrm{R}}$ & 0 & 0 & 1.56 & $>0.05$ & $>0.05$ & $>0.05$ \\
\hline & W & 15.15 & 3.17 & 4.69 & $<0.05$ & $=0.074$ & $>0.05$ \\
\hline & $\mathrm{CP}$ & 0 & 28.57 & 6.25 & $<0.001$ & $>0.05$ & $<0.01$ \\
\hline & LP & 0 & 4.76 & 0 & $>0.05$ & $>0.05$ & $=0.080$ \\
\hline & $\mathrm{DL}$ & 3.03 & 0 & 0 & $>0.05$ & $>0.05$ & $>0.05$ \\
\hline & $\mathrm{RP}$ & 0 & 1.59 & 14.06 & $>0.05$ & $<0.05$ & $<0.05$ \\
\hline
\end{tabular}

Notes: here and thereafter, $A$ - arc; $L^{U}$ - ulnar loop; $L^{R}$ - radial loop W - whorl; CP - central pocket; LP - lateral pocket loop; DL - double loop; RP - random pattern.
Table 2. Distribution of type of finger patterns on the right hand in young women with allergic rhinitis, bronchial asthma and atopic dermatitis (\%)

\begin{tabular}{|c|c|c|c|c|c|c|c|}
\hline Finger & $\begin{array}{c}\text { Type } \\
\text { of } \\
\text { pattern }\end{array}$ & $\begin{array}{c}\text { Patients } \\
\text { with } A R \\
(n=33) \\
(1)\end{array}$ & $\begin{array}{c}\begin{array}{c}\text { Patients } \\
\text { with BA } \\
(\mathrm{n}=45) \\
(2)\end{array}\end{array}$ & $\begin{array}{c}\text { Patients } \\
\text { with } A D \\
(n=79) \\
(3)\end{array}$ & $p_{1-2}$ & $p_{1-3}$ & $p_{2-3}$ \\
\hline \multirow{8}{*}{ R-I } & A & 2.78 & 11.11 & 8.86 & $>0.05$ & $>0.05$ & $>0.05$ \\
\hline & $\mathrm{Lu}^{\mathrm{u}}$ & 36.11 & 6.67 & 49.37 & $<0.01$ & $>0.05$ & $<0.001$ \\
\hline & $L^{R}$ & 0 & 0 & 0 & $>0.05$ & $>0.05$ & $>0.05$ \\
\hline & W & 36.11 & 4.44 & 10.13 & $<0.001$ & $<0.01$ & $>0.05$ \\
\hline & $\mathrm{CP}$ & 5.56 & 48.89 & 11.39 & $<0.001$ & $>0.05$ & $<0.001$ \\
\hline & LP & 0 & 0 & 0 & $>0.05$ & $>0.05$ & $>0.05$ \\
\hline & $\mathrm{DL}$ & 19.44 & 13.33 & 12.66 & $>0.05$ & $>0.05$ & $>0.05$ \\
\hline & $\mathrm{RP}$ & 0 & 15.56 & 7.59 & $<0.05$ & $>0.05$ & $>0.05$ \\
\hline \multirow{8}{*}{ R-II } & A & 13.89 & 15.56 & 40.51 & $>0.05$ & $<0.01$ & $<0.01$ \\
\hline & $L^{u}$ & 19.44 & 22.22 & 22.78 & $>0.05$ & $>0.05$ & $>0.05$ \\
\hline & $L^{R}$ & 11.11 & 6.67 & 1.27 & $>0.05$ & $<0.05$ & $>0.05$ \\
\hline & $w$ & 38.89 & 28.89 & 10.13 & $>0.05$ & $<0.001$ & $<0.01$ \\
\hline & $\mathrm{CP}$ & 5.56 & 22.22 & 17.72 & $<0.05$ & $=0.095$ & $>0.05$ \\
\hline & LP & 0 & 6.67 & 0 & $>0.05$ & $>0.05$ & $<0.05$ \\
\hline & $\mathrm{DL}$ & 11.11 & 4.44 & 3.80 & $>0.05$ & $>0.05$ & $>0.05$ \\
\hline & RP & 0 & 0 & 3.80 & $>0.05$ & $>0.05$ & $>0.05$ \\
\hline \multirow{8}{*}{ R-III } & A & 11.11 & 6.67 & 24.05 & $>0.05$ & $>0.05$ & $<0.05$ \\
\hline & $L^{u}$ & 44.44 & 46.67 & 51.90 & $>0.05$ & $>0.05$ & $>0.05$ \\
\hline & $L^{R}$ & 0 & 0 & 0 & $>0.05$ & $>0.05$ & $>0.05$ \\
\hline & W & 30.56 & 31.11 & 3.80 & $>0.05$ & $<0.001$ & $<0.001$ \\
\hline & $\mathrm{CP}$ & 5.56 & 13.33 & 10.13 & $>0.05$ & $>0.05$ & $>0.05$ \\
\hline & LP & 2.78 & 2.22 & 0 & $>0.05$ & $>0.05$ & $>0.05$ \\
\hline & $\mathrm{DL}$ & 5.56 & 0 & 2.53 & $>0.05$ & $>0.05$ & $>0.05$ \\
\hline & $\mathrm{RP}$ & 0 & 0 & 7.59 & $>0.05$ & $>0.05$ & $=0.061$ \\
\hline \multirow{8}{*}{ R-IV } & A & 5.56 & 6.67 & 17.72 & $>0.05$ & $=0.095$ & $=0.088$ \\
\hline & $L^{u}$ & 25.00 & 57.78 & 34.18 & $<0.01$ & $>0.05$ & $<0.05$ \\
\hline & $L^{R}$ & 0 & 0 & 0 & $>0.05$ & $>0.05$ & $>0.05$ \\
\hline & W & 55.56 & 11.11 & 17.72 & $<0.001$ & $<0.001$ & $>0.05$ \\
\hline & $\mathrm{CP}$ & 11.11 & 24.44 & 13.92 & $>0.05$ & $>0.05$ & $>0.05$ \\
\hline & LP & 2.78 & 0 & 0 & $>0.05$ & $>0.05$ & $>0.05$ \\
\hline & $\mathrm{DL}$ & 0 & 0 & 1.27 & $>0.05$ & $>0.05$ & $>0.05$ \\
\hline & $\mathrm{RP}$ & 0 & 0 & 15.19 & $>0.05$ & $<0.05$ & $<0.01$ \\
\hline \multirow{8}{*}{$R-V$} & A & 0 & 6.67 & 17.72 & $>0.05$ & $<0.05$ & $=0.088$ \\
\hline & $L^{u}$ & 75.00 & 80.00 & 62.03 & $>0.05$ & $>0.05$ & $<0.05$ \\
\hline & $L^{R}$ & 2.78 & 1.27 & 0 & $>0.05$ & $>0.05$ & $>0.05$ \\
\hline & $w$ & 5.56 & 0 & 2.53 & $>0.05$ & $>0.05$ & $>0.05$ \\
\hline & $\mathrm{CP}$ & 16.67 & 2.22 & 6.33 & $<0.05$ & $=0.090$ & $>0.05$ \\
\hline & LP & 0 & 8.89 & 0 & $=0.083$ & $>0.05$ & $<0.01$ \\
\hline & $\mathrm{DL}$ & 0 & 0 & 1.27 & $>0.05$ & $>0.05$ & $>0.05$ \\
\hline & $\mathrm{RP}$ & 0 & 2.22 & 10.13 & $>0.05$ & $=0.060$ & $>0.05$ \\
\hline
\end{tabular}

there no whorl; and on the IV finger - the central pocket, on this finger, usually (more than 6 times more often), a whorl 
Table 3. Distribution of type of finger patterns on the left hand in young men with allergic rhinitis, bronchial asthma and atopic dermatitis (\%).

\begin{tabular}{|c|c|c|c|c|c|c|c|}
\hline Finger & $\begin{array}{c}\text { Type } \\
\text { of } \\
\text { pattern }\end{array}$ & $\begin{array}{c}\text { Patients } \\
\text { with AR } \\
(\mathrm{n}=36) \\
(1)\end{array}$ & $\begin{array}{c}\text { Patients } \\
\text { with BA } \\
(\mathrm{n}=63) \\
(2)\end{array}$ & $\begin{array}{c}\text { Patients } \\
\text { with } A D \\
(n=64) \\
(3)\end{array}$ & $p_{1-2}$ & $p_{1-3}$ & $p_{2-3}$ \\
\hline \multirow{8}{*}{ L-I } & A & 3.03 & 12.70 & 9.37 & $>0.05$ & $>0.05$ & $>0.05$ \\
\hline & $\mathrm{Lu}^{U}$ & 75.76 & 41.27 & 54.69 & $<0.01$ & $<0.05$ & $>0.05$ \\
\hline & $L^{R}$ & 0 & 0 & 0 & $>0.05$ & $>0.05$ & $>0.05$ \\
\hline & W & 12.12 & 3.17 & 6.25 & $=0.084$ & $>0.05$ & $>0.05$ \\
\hline & $\mathrm{CP}$ & 0 & 7.94 & 14.06 & $=0.086$ & $<0.05$ & $>0.05$ \\
\hline & LP & 0 & 15.87 & 0 & $<0.05$ & $>0.05$ & $<0.01$ \\
\hline & $\mathrm{DL}$ & 9.09 & 14.29 & 6.25 & $>0.05$ & $>0.05$ & $>0.05$ \\
\hline & $\mathrm{RP}$ & 0 & 4.76 & 9.37 & $>0.05$ & $=0.061$ & $>0.05$ \\
\hline \multirow{8}{*}{ L-II } & A & 36.36 & 14.29 & 35.94 & $<0.05$ & $>0.05$ & $<0.01$ \\
\hline & $L^{U}$ & 33.33 & 25.40 & 29.69 & $>0.05$ & $>0.05$ & $>0.05$ \\
\hline & $L^{R}$ & 3.03 & 4.23 & 3.12 & $>0.05$ & $>0.05$ & $>0.05$ \\
\hline & W & 21.21 & 25.40 & 9.37 & $>0.05$ & $>0.05$ & $<0.05$ \\
\hline & $\mathrm{CP}$ & 0 & 22.22 & 6.25 & $<0.01$ & $>0.05$ & $<0.05$ \\
\hline & LP & 0 & 3.17 & 0 & $>0.05$ & $>0.05$ & $>0.05$ \\
\hline & $\mathrm{DL}$ & 6.06 & 6.35 & 10.94 & $>0.05$ & $>0.05$ & $>0.05$ \\
\hline & $\mathrm{RP}$ & 0 & 3.17 & 4.69 & $>0.05$ & $>0.05$ & $>0.05$ \\
\hline \multirow{8}{*}{ L-III } & A & 6.06 & 6.35 & 17.19 & $>0.05$ & $>0.05$ & $=0,061$ \\
\hline & $L^{u}$ & 72.73 & 58.73 & 59.38 & $>0.05$ & $>0.05$ & $>0.05$ \\
\hline & $L^{R}$ & 0 & 1.11 & 1.56 & $>0.05$ & $>0.05$ & $>0.05$ \\
\hline & W & 18.18 & 7.94 & 4.69 & $>0.05$ & $<0.05$ & $>0.05$ \\
\hline & $\mathrm{CP}$ & 0 & 14.29 & 10.94 & $<0.05$ & $<0.05$ & $>0.05$ \\
\hline & LP & 0 & 4.76 & 0 & $>0.05$ & $>0.05$ & $=0.080$ \\
\hline & $\mathrm{DL}$ & 3.03 & 0 & 3.12 & $>0.05$ & $>0.05$ & $>0.05$ \\
\hline & $\mathrm{RP}$ & 0 & 7.94 & 3.12 & $=0.086$ & $>0.05$ & $>0.05$ \\
\hline \multirow{8}{*}{ L-IV } & A & 6.06 & 15.87 & 4.69 & $>0.05$ & $>0.05$ & $<0.05$ \\
\hline & $\mathrm{Lu}^{u}$ & 57.58 & 46.03 & 45.31 & $>0.05$ & $>0.05$ & $>0.05$ \\
\hline & $L^{R}$ & 0 & 0 & 0 & $>0.05$ & $>0.05$ & $>0.05$ \\
\hline & W & 30.30 & 4.76 & 7.81 & $<0.001$ & $<0.01$ & $>0.05$ \\
\hline & $\mathrm{CP}$ & 0 & 23.81 & 20.31 & $<0.01$ & $<0.01$ & $>0.05$ \\
\hline & LP & 0 & 9.52 & 0 & $=0.059$ & $>0.05$ & $<0.05$ \\
\hline & $\mathrm{DL}$ & 3.03 & 0 & 1.56 & $>0.05$ & $>0.05$ & $>0.05$ \\
\hline & $\mathrm{RP}$ & 3.03 & 0 & 20.31 & $>0.05$ & $<0.05$ & $<0.001$ \\
\hline \multirow{8}{*}{ L-V } & $A$ & 6.06 & 0 & 6.25 & $=0.051$ & $>0.05$ & $<0.05$ \\
\hline & $L^{u}$ & 78.79 & 63.49 & 68.75 & $>0.05$ & $>0.05$ & $>0.05$ \\
\hline & $L^{R}$ & 0 & 1.54 & 3.12 & $>0.05$ & $>0.05$ & $>0.05$ \\
\hline & W & 15.15 & 1.59 & 3.12 & $<0.01$ & $<0.05$ & $>0.05$ \\
\hline & $\mathrm{CP}$ & 0 & 20.63 & 4.69 & $<0.01$ & $>0.05$ & $<0.01$ \\
\hline & LP & 0 & 9.52 & 0 & $=0.059$ & $>0.05$ & $<0.05$ \\
\hline & $\mathrm{DL}$ & 0 & 0 & 1.56 & $>0.05$ & $>0.05$ & $>0.05$ \\
\hline & $\mathrm{RP}$ & 0 & 4.76 & 12.50 & $>0.05$ & $<0.05$ & $>0.05$ \\
\hline
\end{tabular}

is placed; on the $\mathrm{V}$ finger, the whorl is most often located (almost 10 times more often) and the central pocket is not
Table 4. Distribution of type of finger patterns on the left hand in young women with allergic rhinitis, bronchial asthma and atopic dermatitis (\%)

\begin{tabular}{|c|c|c|c|c|c|c|c|}
\hline Finger & $\begin{array}{c}\text { Type } \\
\text { of } \\
\text { pattern }\end{array}$ & $\begin{array}{c}\text { Patients } \\
\text { with AR } \\
(n=33) \\
(1)\end{array}$ & \begin{tabular}{|c} 
Patients \\
with BA \\
$(\mathrm{n}=45)$ \\
$(2)$
\end{tabular} & $\begin{array}{c}\text { Patients } \\
\text { with } A D \\
(n=79) \\
(3)\end{array}$ & $p_{1-2}$ & $p_{1-3}$ & $p_{2-3}$ \\
\hline \multirow{8}{*}{ L-I } & A & 22.22 & 11.11 & 10.13 & $>0.05$ & $=0.093$ & $>0.05$ \\
\hline & $L^{U}$ & 44.44 & 64.44 & 55.70 & $=0.083$ & $>0.05$ & $>0.05$ \\
\hline & $\mathrm{L}^{\mathrm{R}}$ & 0 & 0 & 0 & $>0.05$ & $>0.05$ & $>0.05$ \\
\hline & W & 13.89 & 2.22 & 2.53 & $=0.052$ & $<0.05$ & $>0.05$ \\
\hline & $\mathrm{CP}$ & 2.78 & 15.56 & 6.33 & $=0.069$ & $>0.05$ & $=0.097$ \\
\hline & LP & 2.78 & 2.22 & 0 & $>0.05$ & $>0.05$ & $>0.05$ \\
\hline & $\mathrm{DL}$ & 13.89 & 4.44 & 18.99 & $>0.05$ & $>0.05$ & $<0.05$ \\
\hline & $\mathrm{RP}$ & 0 & 0 & 6.33 & $>0.05$ & $>0.05$ & $=0,087$ \\
\hline \multirow{8}{*}{ L-II } & A & 11.11 & 0 & 40.51 & $<0.05$ & $<0.01$ & $<0.001$ \\
\hline & $L^{U}$ & 33.33 & 20.00 & 24.05 & $>0.05$ & $>0.05$ & $>0.05$ \\
\hline & $L^{R}$ & 8.33 & 7.68 & 5.06 & $>0.05$ & $>0.05$ & $>0.05$ \\
\hline & W & 30.56 & 33.33 & 11.39 & $>0.05$ & $<0.05$ & $<0.01$ \\
\hline & $\mathrm{CP}$ & 16.67 & 24.44 & 5.06 & $>0.05$ & $<0.05$ & $<0.01$ \\
\hline & LP & 0 & 4.44 & 0 & $>0.05$ & $>0.05$ & $=0.061$ \\
\hline & $\mathrm{DL}$ & 0 & 17.78 & 8.86 & $<0.05$ & $=0.080$ & $>0.05$ \\
\hline & $\mathrm{RP}$ & 0 & 0 & 5.06 & $>0.05$ & $>0.05$ & $>0.05$ \\
\hline \multirow{8}{*}{ L-III } & A & 8.33 & 8.89 & 25.32 & $>0.05$ & $<0.05$ & $<0.05$ \\
\hline & $L^{U}$ & 50.00 & 62.22 & 56.96 & $>0.05$ & $>0.05$ & $>0.05$ \\
\hline & $L^{R}$ & 0 & 0 & 0 & $>0.05$ & $>0.05$ & $>0.05$ \\
\hline & W & 22.22 & 20.00 & 3.80 & $>0.05$ & $<0.01$ & $<0.01$ \\
\hline & $\mathrm{CP}$ & 19.44 & 0 & 6.33 & $<0.05$ & $<0.01$ & $=0.087$ \\
\hline & LP & 0 & 0 & 0 & $>0.05$ & $>0.05$ & $>0.05$ \\
\hline & $\mathrm{DL}$ & 0 & 6.67 & 1.27 & $>0.05$ & $>0.05$ & $>0.05$ \\
\hline & $\mathrm{RP}$ & 0 & 2.22 & 6.33 & $>0.05$ & $>0.05$ & $>0.05$ \\
\hline \multirow{8}{*}{ L-N } & A & 8.33 & 15.56 & 21.52 & $>0.05$ & $=0.098$ & $>0.05$ \\
\hline & $L^{U}$ & 25.00 & 44.44 & 34.18 & $=0.082$ & $>0.05$ & $>0.05$ \\
\hline & $L^{R}$ & 0 & 0 & 1.27 & $>0.05$ & $>0.05$ & $>0.05$ \\
\hline & W & 55.56 & 15.56 & 10.13 & $<0.001$ & $<0.001$ & $>0.05$ \\
\hline & $\mathrm{CP}$ & 11.11 & 0 & 13.92 & $<0.05$ & $>0.05$ & $<0.01$ \\
\hline & LP & 0 & 17.78 & 0 & $<0.05$ & $>0.05$ & $<0.001$ \\
\hline & $\mathrm{DL}$ & 0 & 6,67 & 3.80 & $>0.05$ & $>0.05$ & $>0.05$ \\
\hline & $\mathrm{RP}$ & 0 & 0 & 15.19 & $>0.05$ & $<0.05$ & $<0.01$ \\
\hline \multirow{8}{*}{ L-V } & A & 2.78 & 0 & 20.25 & $>0.05$ & $<0.05$ & $<0.01$ \\
\hline & $L^{U}$ & 63.89 & 86.67 & 62.03 & $<0.05$ & $>0.05$ & $<0.01$ \\
\hline & $L^{R}$ & 2.78 & 1.08 & 0 & $>0.05$ & $>0.05$ & $>0.05$ \\
\hline & W & 22.22 & 0 & 3.80 & $<0.01$ & $<0.01$ & $>0.05$ \\
\hline & $\mathrm{CP}$ & 8.33 & 11.11 & 10.13 & $>0.05$ & $>0.05$ & $>0.05$ \\
\hline & LP & 0 & 2.22 & 0 & $>0.05$ & $>0.05$ & $>0.05$ \\
\hline & $\mathrm{DL}$ & 0 & 0 & 0 & $>0.05$ & $>0.05$ & $>0.05$ \\
\hline & $\mathrm{RP}$ & 0 & 0 & 3.80 & $>0.05$ & $>0.05$ & $>0.05$ \\
\hline
\end{tabular}

found (see Table 2). Thus, out of 40 analyzed positions of indicators of the left hand, 9 of them received reliable 
differences between patients in the AR and BA. In total, 80 analyzed positions of the indicators of both hands, 21 of them received significant differences between the young men, patients with AR and BA.

In young men, patients with $A R$ in comparison with patients with $A D$, on the right hand there is no whorl on the I finger; on II finger 3 times more often there is a whorl; on the III finger 4 times less common arc; on IV finger, as a rule, a whorl is recorded (almost 4 times more often); on the $\mathrm{V}$ finger, a random pattern is never localized (see Table 1). Thus, out of 40 analyzed positions of indicators of the right hand, 7 of them received reliable differences between young men, patients with $A R$ and $A D$.

In young men, patients with $A R$ in comparison with patients with $A D$, on the left hand on the I finger, almost 1.4 times more often, there is an ulnar loop and the central pocket is not found; on the II finger localization of patterns without differences; on the III and IV fingers never observed the central pocket and 4 times more often the whorl is detected; on the $\mathrm{V}$ finger, the whorl is most often located (almost 5 times more often) and there is no random pattern (see Table 2). Thus, out of 40 analyzed positions of indicators of the left hand, 9 of them received reliable differences between patients in the AR and BA. In total of 80 analyzed positions of indicators of both hands, 16 of them received reliable differences between young men, patients with $A R$ and AD.

In young men, patients with $A D$ in comparison with patients with $\mathrm{BA}$, on the right hand there is a prevalence of double loop on the I finger (3 times more often), an arc is extremely rare (4 times) and the lateral pocket loop is never found; on the II finger 2.5 times less is the central pocket; on the III finger 2.6 times the arc is more common; on IV finger, as a rule, a whorl is recorded (more than 4 times more often); on the $V$ finger, the central pocket is 4.5 times less likely to be localized and the random pattern appears more often (almost 9 times) (see Table 1). Thus, out of 40 analyzed positions of indicators of the right hand, 8 of them received reliable differences between young men, patients with $A D$ and BA.

In young men, patients with $A D$ compared to patients with $\mathrm{BA}$, on the left hand on the I finger never encounter a lateral pocket loop; on the II finger, the arc dominates (2.5 times), the whorl is less frequently (2.7 times) and the central pocket (3.6 times); on the III finger the differences were not recorded; on the IV finger, usually, a random pattern is placed, an arc rarely occurs (3.3 times) and a lateral pocket loop does not occur; on the $\mathrm{V}$ finger there is an arc, the central pocket is less common (4.4 times), and the lateral pocket loop is never localized (see Table 2). Thus, out of 40 analyzed positions of the indicators of the left hand, 10 of them received reliable differences between patients with $A D$ and $B A$. In total of 80 analyzed positions of indicators of both hand, 18 of them received reliable differences between young men, patients with $A D$ and $B A$.

In young women, patients with $A R$ in comparison with patients with $\mathrm{BA}$, on the right hand on the I finger more than 8 times more often there is a whorl, 6 times - ulnar loop, extremely rare (the difference is almost 9 times) - the central pocket is found and does not occur random pattern; on the II finger rarely (difference in 4 times) the central pocket is detected; no difference was found on the III finger; on the IV finger the whorl is dominant (5 times more often), the ulnar loop is more likely to occur (2 times); the central pocket is more often located on the $\mathrm{V}$ finger ( 7.5 times more often) (see Table 3). Thus, out of 40 analyzed positions of indicators of the right hand, 8 of them obtained reliable differences between patients in the AR and BA.

In young women, patients with $A R$ in comparison with patients with BA, on the left hand on the I finger no significant differences were found; on the II finger there is an arc and the double loop is not localized $(11.11 \%$ and $0 \%)$, in contrast to patients with BA ( $0 \%$ and $17.78 \%)$; the central pocket appears on the III finger, and it never happens here in patients with BA; on IV finger, 3.6 times more often, a whorl is recorded, or a central pocket is detected that does not occur in patients with BA and, on the contrary, never the lateral pocket loop observed when it is present in patients with BA; a whorl is placed on the $V$ finger (in the absence of patients with $B A$ ) and the ulnar loop is less common. Thus, out of 40 analyzed positions of indicators of the left hand, 8 of them received reliable differences between patients in the AR and BA (see Table 4). In total, 80 analyzed positions of indicators of both hands, 16 of them received reliable differences between young women, patients with AR and BA.

In young women, patients with $A R$ in comparison with patients with $A D$, on the right hand on the I finger 3.6 times more often localized whorl; on the II finger 3 times more often there is a whorl and 3 times less arc; on a III finger 8 times more often there is a whorl; on IV finger, as a rule, a whorl is recorded ( 3 times more often) and there is no accidental pattern; on the $\mathrm{V}$ finger never observed an arc (see Table 3). Thus, out of 40 analyzed positions of indicators of the right hand, in 7 of them, there were significant differences between young women, patients with AR and AD.

In young women, patients with $A R$ in comparison with patients with $A D$, on the left hand on I finger whorl is 5.5 times more likely to be encountered; on the II finger, the whorl and the central pocket (2.7 and 3.3 times respectively) and 3.6 times less often - arc are localized; on the III finger, the whorls and central pockets (5.8 and 3.1 times, respectively) are localized and 3 times less often - the arc; on the IV finger, the random pattern is never localized and the whorl is detected 5.5 times more often; whorls are often placed on the $\mathrm{V}$ finger (5.8 times more often) and the arch is less common (7 times) (see Table 4). Thus, out of 40 analyzed positions of indicators of the left hand, 11 of them received reliable differences between patients in the AR and $A D$. In total of 80 analyzed positions of indicators of both hands, 18 of them received reliable differences between young women, patients with AR and AD. 
In young women, patients with $A D$, in comparison with patients with BA, the ulnar loop ( 7 times more often) and the central pocket (4 times) are more common on the right hand on the I finger; on the II finger, the arch is registered 2.6 times more often and almost 3 times less often - whorl and never a lateral pocket loop; on the III finger - 3.6 times arc is more often encountered and 8 times less frequently - a whorl; on the IV finger a random pattern appears, unlike patients with $\mathrm{BA}$, in which it never localizes on this finger and less often the ulnar loop (1.7 times); on the $V$ finger, the ulnar loop is detected (in patients with asthma, it never locates on this finger), and never, unlike BA patients, the lateral pocket loop does not appear (see Table 3). Thus, out of 40 analyzed positions of indicators of the right hand, by 11 of them received reliable differences between patients with $A D$ and $B A$.

In young women, patients with $A D$ compared to patients with $B A$, on the left hand on the I finger dominates the double loop (4.3 times more often); on the II finger often observed arc (in patients with BA is not localized), rarely there is a whorl and central pockets (in 3 and 4.8 times respectively); on the III finger also the arc dominates (2.8 times) and the whorl is less common ( 5 times); a central pocket and a random pattern are recorded on the IV finger (in patients with BA they never localize on this finger) and the lateral pocket loop is not detected (in patients with BA is detected); on the $\mathrm{V}$ finger is observed an arc (in patients with asthma is not detected), rarely, the ulnar loop is observed (1.4 times) (see Table 4). Thus, out of 40 analyzed positions of indicators of the left hand, 11 of them received reliable differences between patients with $A D$ and $B A$. In total, 80 analyzed positions of indicators of both hands, by 22 of them received reliable differences between young women, patients with $A D$ and $B A$.

\section{Discussion}

In studies of a number of authors, by comparing the qualitative indexes of digital dermatoglyphics of healthy and sick people, associations of an atopic phenotype with typological features of papillary skin have been established. Gara A. V. and others [7] shows that the dermatoglyphic picture of patients with AD is characterized by simplicity of finger patterns with predominance of arches and random patterns. Work of Gunas I. V. and others [9] shows that dermatotype of adolescents with BA, is characterized by a reduced frequency of ulnar loops and increased - lateral pocket loops. The associative association of AR with signs of dermatoglyphics manifests itself in deviations in the frequency and localization of whorls, central pockets, ulnar loops and arches both in young men and in young women [2].

The results of our study showed that finger dermatoglyphics in young men, patients with $A D, A R$ and $B A$, in the first place, differ in frequency and localization of whorls, central pockets and arches. Additionally, patients with AR differ from patients both with $B A$ and $A D$ by frequency and localization of the ulnar loop. Patients with BA are additionally different from patients with $A R$ and $A D$ in frequency and localization of the lateral pocket loop. Patients with $A D$ are additionally different from patients with $B A$ and $A R$ in frequency and localization of random patterns. The share of these differences is about a quarter of all the analyzed indicators. The greatest number of differences was found when comparing qualitative indicators of digital dermatoglyphics in young men, patients with $\mathrm{AR}$ and $\mathrm{BA}(26.25 \%)$, the smallest - patients with $A R$ and $A D(20.0 \%)$, the differences between patients with $A D$ and BA cover $22.5 \%$ of all analyzed. It should be noted that when comparing the dermatoglyphics of patients with $A R$ and $B A$, more differences were found on the fingers of the right hand compared with the left $(30.0 \%$ versus $22.5 \%$ ). On the contrary, when comparing dermatoglyphics of patients with $A D$ with dermatoglyphics of patients with $A R$ and $B A$, more differences were found on the fingers of the left hand compared to the right $(22.5 \%$ vs. $17.5 \%$ and $25.0 \%$ vs. $20.0 \%$ respectively).

Finger dermatoglyphics of young women, patients with $A D, A R$ and $B A$, in the first place, differ in frequency and localization of whorls, central pockets, arches and random patterns. Additionally, patients with asthma differ from patients both in $A R$, and $A D$ in frequency and localization of ulnar loops, lateral pocket loops and double loops. In young women, as in young men, the part of these differences is also about a quarter of all analyzed indicators. However, the greatest number of differences was found when comparing qualitative indicators of digital dermatoglyphics in young women, patients with $\mathrm{AD}$ and $\mathrm{BA}(27.5 \%)$, the smallest patients with AR and BA $(20.0 \%)$, the differences between patients with $A D$ and $A R$ cover $22.5 \%$ of all analyzed. It should be noted that when comparing dermatoglyphics of patients with $A R$ and $A D$, more differences were found on the fingers of the left hand compared to the right $(27.5 \%$ versus $15.5 \%)$. The same number of differences is found on the fingers of both the left and right hand when comparing young women, patients with BA and AR, as well as - BA and AD (by $20.0 \%$ and $27.5 \%$ respectively).

The presence of a general trend of changes in digital dermatoglyphics when comparing the differences between patients with $A D, B A$ and $A R$ (in young men: whorl, central pocket and arc; in young women: whorl, central pocket, arc and random pattern) indicates the common "roots" of the formation of atopic phenotype, additional differences found (in young men: when comparing $A R$ and with $B A$, and with $A D$ - ulnar loop; when comparing $B A$ with and with $A R$, and with $A D$ - lateral pocket loop; when comparing $A D$ and with $B A$, and with $A R$ - random pattern; in young women: when comparing $B A$ with and with $A R$, and with $A D$ - ulnar loop, lateral pocket loop and double loop) indicate the pathogenetic heterogeneity of atopic diseases.

Detected associations of atopic diseases with typological peculiarities of papillary skin of sick young men and young women can be used as marker signs of probability in the further launch of the "atopic march". 


\section{Conclusions}

1. Differences in qualitative signs of digital dermatoglyphics between young men, patients with $A D, B A$ and $A R$, are observed by the frequency and localization of whorl, central pocket and arch, in addition when comparing patients with allergic rhinitis with patients with bronchial asthma and atopic dermatitis - ulnar loop, with comparison of patients with bronchial asthma with allergic rhinitis and atopic dermatitis - lateral pocket loop; when comparing

\section{References}

[1]Akinbami, L. J., Moorman, J. E., Bailey, C., Zahran, H. S., King, M., Johnson, C. A., \& Liu, X. (2012). Trends in asthma prevalence, health care use, and mortality in the United States, 2001-2010. NCHS data brief, 94, 1-8.

[2] Antonets, T. I. (2003). Peculiarities of finger dermatoglyphics in urban adolescents in the Podillia region of Ukraine with allergic rhinitis. Problems, achievements and prospects for the development of biomedical sciences and practical public health. Proceedings of the Crimean State Medical University n.a. S.I. Georgievsky, 6(4), 13-19.

[3] Berke, R., Singh, A., \& Guralnick, M. (2012). Atopic dermatitis: an overview. American Family Physician, 86(1), 35-42.

[4] Chatterjee, P., Bandyopadhyay, A., Chatterjee, P., \& Nandy, P. (2019). Assessment and Comparative Analysis of Different Lung Capacities in Trained Athletes According to Somatotype. American Journal of Sports Science, 7(2), 72-77. doi: 10.11648/j.ajss.20190702.14

[5] Cummins, H., \& Midlo, Ch. (1961). Finger Prints, Palms and Soles. An Introduction to Dermatoglyphics. Philadelphia.

[6] Ferreira, M. A., Matheson, M. C., Tang, C. S., Granell, R., Ang, W., Hui, J., ... Bui, M. (2014). Genome-wide association analysis identifies 11 risk variants associated with the asthma with hay fever phenotype. Journal of Allergy and Clinical Immunology, 133(6), 1564-1571. https://doi.org/10.1016/ j.jaci.2013.10.030

[7] Gara, A. V., Mateshuk-Watseba, L. R., Klimas, L. A., \& Ocheretna, O. L. (2012). Clinically significant variants of digital dermatoglyphics in girls suffering from atopic dermatitis. Bulletin of Vinnitsa National Medical University, 1(16), 4349.

[8] Gladkova, T. D. (1966). Skin patterns of the hand and foot of monkeys and humans. M.: Science.

[9] Gunas, I. V., Protsiuk, T. L., Klimas, L. A., \& Kaminska, N. A. (2007). Features of finger dermatoglyphics in children of school age with bronchial asthma. Bulletin of Vinnitsa National Medical University, 11(1-2), 400-403.

[10] Gunas, V. I. (2018). Modeling using discrimination analysis, priority of practically healthy men to northern or other administrative-territorial regions of Ukraine on the basis of dermatoglyphic indicators features. World of Medicine and Biology, 1(63), 74-87. doi: 10.26724/2079-8334-2018-1-639-14

[11] Han, Y. Y., Forno, E., Gogna, M., \& Celed?n, J. C. (2016). Obesity and rhinitis in a nationwide study of children and adults in the United States. Journal of Allergy and Clinical Immunology, 137(5), 1460-1465. https://doi.org/10.1016/ j.jaci.2015.12.1307

[12] Hanifin, J. M., \& Rajka, G. (1980). Diagnostic features of atopic dermatitis. Acta Dermatol. Venereol., 92, 44.

[13] Hiru, N., \& Kumar, P. (2017). Study of Dermatoglyphics in Children Age 5-18 Years with Bronchial Asthma. Indian Journal patients with atopic dermatitis with patients with bronchial asthma, and allergic rhinitis - a random pattern.

2. Differences in qualitative signs of digital dermatoglyphics between young women, patients with $A D$, $B A$ and $A R$, are observed by the frequency and localization of whorl, central pocket, arch and random pattern, in addition when comparing patients with bronchial asthma with patients with allergic rhinitis and atopic dermatitis - ulnar, lateral pocket and double loops.

of Public Health Research \& Development, 8(2), 300-304. doi: 10.5958/0976-5506.2017.00130.9

[14] Hjellvik, V., Tverdal, A., \& Furu, K. (2010). Body mass index as predictor for asthma: a cohort study of 118,723 males and females. European Respiratory Journal, 35(6), 1235-1242. doi: 10.1183/09031936.00192408

[15] Hwang, C. Y., Chen, Y. J., Lin, M. W., Chen, T. J., Chu, S. Y., Chen, C. C., ... Liu, H. N. (2010). Prevalence of atopic dermatitis, allergic rhinitis and asthma in Taiwan: a national study 2000 to 2007. Acta dermato-venereologica, 90(6), 589-594. https:// doi.org/10.2340/00015555-0963

[16] Hwang, S. H., Jung, S. Y., Lim, D. H., Son, B. K., Kim, J. H., Yang, J. M., ... Kim, S. Y. (2013). Epidemiology of allergic rhinitis in Korean children. Allergy, Asthma \& Respiratory Disease, 1(4), 321-332. https://doi.org/10.4168/ aard.2013.1.4.321

[17] Khan, M., Khan, M. A., Shabbir, F., \& Rajput, T. A. (2013). Association of allergic rhinitis with gender and asthma. Journal of Ayub Medical College Abbottabad, 25(1-2), 120-122.

[18] Koo, H., Lee, S. M., Lee, S. P., \& Han, E. (2014). Association of body mass index with asthma, allergy rhinitis, and atopic dermatitis among adolescents in Incheon, South Korea. Allergy, Asthma \& Respiratory Disease, 2(4), 243-250. https://doi.org/ 10.4168/aard.2014.2.4.243

[19] Lee, J. H., Han, K. D., Youn, Y. H., Lee, J. Y., Park, Y. G., Lee, S. H., \& Park, Y. M. (2016). Association between obesity, abdominal obesity, and adiposity and the prevalence of atopic dermatitis in young Korean adults: the Korea national health and nutrition examination survey 2008-2010. Allergy, asthma \& immunology research, 8(2), 107-114. https://doi.org/ 10.4168/aair.2016.8.2.107

[20] Manara, A., Habib, M. A., Rahman, M. A., Ayub, M., Begum, N., \& Hossain, S. (2011). Digital and palmar dermatoglyphics in myocardial infarction. Journal of Armed Forces Medical College, Bangladesh, 7(2), 4-8. https://doi.org/10.3329/ jafmc.v7i2.10386

[21] Marera, D. O., Oyieko, W., \& Agumba, G. (2015). Variation in Dermatoglyphic patterns among diabetics in Western Uganda population. African Journal of Science \& Research, 7(3), 2025.

[22] Mims, J. W. (2014, September). Epidemiology of allergic rhinitis. In International forum of allergy \& rhinology, 4(2), 18-20. https:/ /doi.org/10.1002/alr.21385

[23] Pinart, M., Keller, T., Reich, A., Fröhlich, M., Cabieses, B., Hohmann, C., ... Keil, T. (2017). Sex-related allergic rhinitis prevalence switch from childhood to adulthood: a systematic review and meta-analysis. International archives of allergy and immunology, 172(4), 224-235. https://doi.org/10.1159/ 000464324

[24] Rönmark, E. P., Ekerljung, L., Mincheva, R., Sjölander, S., Hagstad, S., Wennergren, G., ... Lundbäck, B. (2016). Different 
risk factor patterns for adult asthma, rhinitis and eczema: results from West Sweden Asthma Study. Clinical and translational allergy, 6(1), 28. https://doi.org/10.1186/s13601016-0112-0

[25] Skaaby, T., Taylor, A. E., Thuesen, B. H., Jacobsen, R. K., Friedrich, N., Mollehave, L. T., ... Völzke, H. (2018). Estimating the causal effect of body mass index on hay fever, asthma and lung function using Mendelian randomization. Allergy, 73(1), 153-164. https://doi.org/10.1111/all.13242

[26] Umlawska, W. (2015). Adipose tissue content and distribution in children and adolescents with bronchial asthma. Respiratory medicine, 109(2), 200-207. doi: 10.1016/j.rmed.2014.11.006.

[27] Weber, E. (1961). Grundriss der biologichen statistic. Aufl. Jena, 4, 13-42.

[28] Yao, T. C., Ou, L. S., Yeh, K. W., Lee, W. I., Chen, L. C., Huang, J. L., \& PATCH Study Group (2011). Associations of age, gender, and BMI with prevalence of allergic diseases in children: PATCH study. Journal of Asthma, 48(5), 503-510. https://doi.org/10.3109/02770903.2011.576743

[29] Yiallouros, P. K., Lamnisos, D., Kolokotroni, O., Moustaki, M., \& Middleton, N. (2013). Associations of body fat percent and body mass index with childhood asthma by age and gender. Obesity, 21(9), 474-482. https://doi.org/10.1002/oby.20284

[30] Zhang, A., \& Silverberg, J. I. (2015). Association of atopic dermatitis with being overweight and obese: a systematic review and metaanalysis. Journal of the American Academy of Dermatology, 72(4), 606-616. https://doi.org/10.1016/ j.jaad.2014.12.013

[31] Zhang, Y., \& Zhang, L. (2014). Prevalence of allergic rhinitis in china. Allergy, asthma \& immunology research, 6(2), 105113. https://doi.org/10.4168/aair.2014.6.2.105

\section{ЯКІСНІ ОЗНАКИ ПАЛЬЦЕВОЇ ДЕРМАТОГЛІФІКИ ЯК МАРКЕРИ ЗАХВОРЮВАНЬ АТОПІЧНОЇ ПРИРОДИ}

\section{Черкасов В. Г., Маєвський О. Є., Сергета І. В., Макарчук І. М., Смолко Н. М.}

Правомірність застосування методу дерматогліфіки у вивченні атопічних захворювань забезпечується полігенністю успадкування ознак дерматогліфьки, з одного боку і патогенетичною гетерогенністю даних захворювань, з іншого боку, а також високою інформативною здатністю ознак дерматогліфіки як маркерів захворювань спадкової та мультисракторіальної природи. Мета дослідження - виявити розбіжності якісних ознак пальцевої дерматогліфьіки між хворими на атопічний дерматит, алергічний риніт та бронхіальну астму. Первинні показники пальцевої дерматогліфріки хворих юнаків $і$ дівчат Подільського регіону взяті з банку даних науково-дослідного центру Вінницького національного медичного університету ім. M. І. Пирогова та були використані в попередніх дослідженнях при порівняні з практично здоровим населенням даного регіону. Відбитки отримані методом "типографської фарби" за Гладковою Т. Д. За методикою Cummins H. i Midlo Ch. проведено дерматогліфрічне дослідження 320 юнаків і дівчат, хворих на алергічний риніт (n=69), бронхіальну астму (n=108) та атопічний дерматит (n=143). Аналізу підлягали частота та локалізація 8 типів пальцевих візерунків. Статистична обробка отриманих результатів проведена в пакеті "Statistica 6.1" з використанням непараметричних методів. Достовірність різниці значень між незалежними якісними величинами визначали за фрормулою Weber E. (1961). Bcmaновлена специфріка пальцевої типології атопічних захворювань, яка полягає у відмінностях за частотою $і$ локалізацією завитка, центральної кишені і дуги між юнаками, крім зазначених - випадкового візерунку між дівчатами, хворими на атопічний дерматит, бронхіальну астму, алергічний риніт. Додатково при порівнянні юнаків, хворих на алергічний риніт з хворими на бронхіальну астму і атопічний дерматит - ульнарної петлі; на бронхіальну астму з хворими на алергічний риніт і атопічний дерматит - латеральної кишенькової петлі (у юнаків) та ульнарної, латеральної кишенькової та подвійної петель (у дівчат); при порівнянні юнаків, хворих на атопічний дерматит з хворими на бронхіальну астму, і алергічний риніт - випадкового візерунка.

Ключові слова: типи пальцевих візерунок, атопічний дерматит, бронхіальна астма, алергічний риніт.

\section{КАЧЕСТВЕННЫЕ ПРИЗНАКИ ПАЛЬЦЕВОЙ ДЕРМАТОГЛИФИКИ КАК МАРКЕРЫ ЗАБОЛЕВАНИЙ АТОПИЧЕСКОЙ ПРИРОДЫ Черкасов В. Г., Маевский А. Е., Сергета И. В., Макарчук И. Н., Смолко Н. Н.}

Правомерность применения метода дерматоглифики в изучении атопических заболеваний обеспечивается полигенностью наследования признаков дерматоглифики, с одной стороны и патогенетической гетерогенностью данных заболеваний, $c$ другой стороны, а также высокой информативной способностью признаков дерматоглифики как маркеров заболеваний наследственной и мультифакториальной природы. Цель исследования - выявить различия качественных признаков пальцевой дерматоглифики между больными атопическим дерматитом, аллергическим ринитом и бронхиальной астмой. Первичные показатели пальцевой дерматоглифики больных юношей и девушек Подольского региона взяты из банка данных научно-исследовательского центра Винницкого национального медицинского университета им. Н. И. Пирогова и были использованы в предыдущих исследованиях при сравнении с практически здоровым населением данного региона. Отпечатки получены методом "типографской краски" по Гладковой Т. Д. По методике Cummins H. и Midlo Ch. проведено дерматоглифическое исследование 320 юношей и девушек, больных аллергическим ринитом (n=69), бронхиальной астмой ( $n=108)$ и атопическим дерматитом (n=143). Анализу подлежали частота и локализация 8 типов пальцевых узоров. Cтатистическая обработка полученных результатов проведена в пакете "Statistica 6.1" с использованием непараметрических методов. Достоверность различий значений между независимыми качественными величинами определяли по формуле Weber E. (1961). Установлена специфика пальцевой типологии атопических заболеваний, которая заключается в различиях по частоте и локализации завитка, центрального кармана и дуги между юношами, кроме указанных - случайного узора между девушками, больными атопическим дерматитом, бронхиальной астмой, аллергическим ринитом. Дополнительно при сравнении юношей, больных аллергическим ринитом с больными бронхиальной астмой и атопическим дерматитом - ульнарной петли; бронхиальной астмой с больными аллергическим ринитом и атопическим дерматитом - латеральной карманной петли (у юношей) и ульнарной, латеральной карманной и двойной петель (у девушек), при сравнении юношей, больных атопическим дерматитом с больными бронхиальной астмой, и аллергическим ринитом - случайного узора. Ключевые слова: типы пальцевых узоров, атопический дерматит, бронхиальная астма, аллергический ринит. 